\title{
A Metodologia da Problematização com o Arco de Maguerez e sua relação com os saberes de professores
}

\author{
Problematization Methodology with Maguerez' Arch \\ and its relation to teachers' knowledge
}

\author{
Andréa Aparecida Colombo ${ }^{1}$; Neusi Aparecida Navas Berbel ${ }^{2}$
}

\section{Resumo}

Com a presente pesquisa, propôs-se uma análise acerca da temática saberes de professores, especificamente a investigação sobre quais são os saberes que podem ser mobilizados/estimulados por meio da Metodologia da Problematização (M.P.) com o Arco de Maguerez (que se constitui com cinco etapas: observação da realidade e definição do problema, pontos-chave, teorização, hipóteses de solução e aplicação à realidade), em seus participantes. Utilizou-se a pesquisa exploratório-descritiva, por meio da literatura que trata de saberes de professores e da Metodologia da Problematização. A pesquisa possibilitou ampliar a compreensão quanto ao grande potencial pedagógico dessa metodologia enquanto método de ensino, de pesquisa ou outras aplicações, como na orientação de Trabalho de Conclusão de Curso - TCC -, pelos saberes que foram associados a cada uma de suas etapas (saberes pedagógicos, curriculares, disciplinares, profissionais, experienciais, entre outros). Reforçou o aprendizado anterior acerca desta temática, tanto pelo processo científico, quanto pela análise crítica desenvolvida a partir do referencial teórico utilizado. Desse modo, ampliou-se a visão de que a M.P. pode ser utilizada na formação de professores, como um processo contínuo que pode incluir pesquisas acerca da docência, como um caminho que estimula a utilização e a aquisição de diferentes saberes, o que permite uma formação ampliada desse profissional, além de prepará-lo para uma ação de transformação da realidade educacional da qual faz parte.

Palavras-chave: Metodologia da problematização. Saberes de professores. Formação de professores.

\begin{abstract}
The purpose of this research is to accomplish an analysis of the theme "teachers' knowledge", more specifically a research on which knowledge can be dealt with/stimulated by the Problematization Methodology (P.M.) and the Maguerez' Arch in the participants, following five stages: observation of reality and definition of problem, key points, theorization, solution hypothesis and application in reality. The exploratory-descriptive research was based the literature that deals with teachers' knowledge as well as the Problematization Methodology. This research made it possible to broaden the understanding of the great pedagogical potential of this methodology while a methods for teaching, research or other uses, as when supervising an end-of-term paper (TCC), by the knowledge that was associated to each of its stages (pedagogical, curricular, discipline, professional, experiential, knowledge, among others). It strengthened the previous knowledge on this theme, not only through the scientific process but also through the critical analysis developed, based on the theoretical framework that was used. Thus it was broadened the idea that the Problematization Methodology can be used in the teachers'
\end{abstract}

\footnotetext{
1 Aluna de Graduação em Pedagogia, com início em 2004 e conclusão em 2007. Bolsista de Iniciação Científica PROIC/UEL, de dez./2005 até o momento. Aluna do $2^{\circ}$ ano de graduação em Língua e Cultura Francesa na UEL. Participação em Projetos de Ensino, de Extensão e de Monitoria Acadêmica durante a graduação. E-mail: deia_uel@yahoo.com.br.

2 Pedagoga, Mestre e Doutora em Educação. Docente do Departamento de Educação desde 1972. Integrante do Programa de Mestrado em Educação da UEL a partir de 1994. E-mail: berbel@uel.br.
} 
education, as a continuing process that may include research on the teaching profession, as a way that stimulates the use and acquisition of different knowledge, leading to a broadened education of this kind of professional, and preparing this professional for transforming the educational context.

Key words: Problematization Methodology. Teachers' Knowledge. Teachers' Education.

\section{Introdução}

A partir de algumas inquietações acerca da formação de professores, entre outros fatores que envolvem essa profissão, selecionamos nesta investigação elementos que permitiram uma análise desse saber tão amplo e complexo, visando sua compreensão.

Propusemo-nos, pois, a analisar qual a contribuição dos autores que tratam dos saberes de professores, definindo como problema: "Quais são os saberes que podem ser mobilizados/estimulados, por meio da Metodologia da Problematização com o Arco de Maguerez, em seus participantes?".

Selecionamos a Metodologia da Problematização, pois sabemos de antemão que a mesma vem sendo desenvolvida na Universidade Estadual de Londrina - UEL, desde 1992, numa perspectiva de educação transformadora. A professora Neusi Berbel, defensora da Metodologia da Problematização, a tem proposto como um caminho de ensino e pesquisa rico, porém complexo, o qual demanda esforços da parte dos que a percorrem, objetivando seguir as cinco etapas do Arco de Maguerez (observação da realidade e definição do problema, pontos-chave, teorização, hipóteses de solução e aplicação à realidade) e alcançar os resultados que suas características apresentam como potencial educativo. A proposta vem sendo divulgada em livros, revistas e sites da Internet.

Este projeto de Iniciação Científica que tem por título "A Metodologia da Problematização com o Arco de Maguerez e sua relação com os saberes de professores" está associado ao projeto maior, intitulado "A teoria e a prática da Metodologia da Problematização com o Arco de Maguerez: um processo em construção".
Tivemos como objetivo geral "Analisar o potencial da Metodologia da Problematização com o Arco de Maguerez para o desenvolvimento de saberes inerentes à formação e atuação do professor, ou de participantes de outras áreas" e como objetivos específicos:

- Descrever as etapas e características da Metodologia da Problematização com o arco de Maguerez, a partir de referenciais que tratam da mesma;

- Identificar um conjunto de saberes, a partir de autores que tratam dessa temática;

- Estabelecer a relação entre as contribuições a respeito dos saberes de professores e as características da Metodologia da Problematização, buscando identificar o potencial dessa metodologia sob esse ponto de vista;

- Elaborar uma síntese do conhecimento adquirido na investigação, como uma contribuição a ser acrescentada aos já existentes sobre a Metodologia da Problematização.

Tendo em vista esses objetivos, optamos, nesta investigação, por um estudo exploratório, analítico e descritivo, combinado com análise documental, a partir de informações colhidas na literatura, disponíveis em livros nas bibliotecas e também em artigos disponíveis no Portal SCIELO.

Apoiamo-nos em Richardson et al. (1999), que descreve o método exploratório como aquele que visa conhecer as características de um fenômeno, para procurar, posteriormente, maiores explicações das razões e das conseqüências do dito fenômeno.

Já o método descritivo, como a palavra dá a entender, visa descrever sistematicamente um fenômeno ou área de interesse, descrição essa 
detalhada e objetiva. As informações foram tratadas de modo a se constituírem em respostas aos questionamentos básicos e aos objetivos da pesquisa. A análise documental, como técnica de pesquisa de dados qualitativos, em geral, apropriada para complementar as informações obtidas por outros meios, foi por nós utilizada para "identificar informações factuais nos documentos a partir de questões ou hipóteses de interesse" (CAULLEY, 1981 apud LÜDKE; ANDRÉ, 1986, p. 38).

São considerados documentos "quaisquer materiais escritos que possam ser usados como fonte de informação sobre o comportamento humano" (PHILLIPS, 1974, apud LÜDKE; ANDRÉ, 1986, p.38). Estes incluem desde leis e regulamentos, normas, pareceres, cartas, memorandos, diários pessoais, autobiografias, jornais, revistas, discursos, roteiros de programas de rádio e televisão até livros, estatísticas e arquivos escolares.

Uma das vantagens na utilização da técnica de análise documental é o fato dos documentos constituírem pontos estáveis, e outra, de poder ser uma técnica de baixo custo, pois requer apenas tempo e atenção na análise.

Todas as informações coletadas e analisadas foram discutidas, buscando-se respostas para os objetivos da investigação que são apresentados na descrição e análise da temática, antecedidos por um breve histórico da Metodologia da Problematização, com suas características.

Consideramos de grande relevância esta investigação, para dar continuidade às já existentes acerca do potencial da Metodologia da Problematização enquanto método de ensino e de pesquisa. $\mathrm{O}$ citado método também pode ser aplicado para o desenvolvimento de projetos de extensão e orientação de Trabalhos de Conclusão de Curso (TCC).

Esta investigação nos proporcionou compreender com maior profundidade o grande potencial pedagógico da Metodologia da Problematização e também reforçou o aprendizado que tínhamos dessa temática, tanto pelo processo científico em si, quanto pela análise crítica desenvolvida a partir do referencial teórico a respeito dos saberes de professores.

Desse modo, ampliou-se nossa visão de formação como pedagoga e futura pedagoga à continuidade de pesquisas acerca da docência na educação, bem como por estudos acerca de problemáticas que envolvam a Metodologia da Problematização, como um componente que pode auxiliar no processo de transformação da realidade educacional.

\section{Um breve histórico da metodologia da problematização e suas características}

O Arco de Maguerez, base para a aplicação da Metodologia da Problematização, foi elaborado na década de 70 do século XX, e tornado público por Bordenave e Pereira (1989) a partir de 1977, mas foi pouco utilizado na época pela área da educação. O livro de Bordenave e Pereira foi, por muito tempo, o único disponível nos meios acadêmicos sobre o Arco de Maguerez, aplicado como um caminho de Educação Problematizadora, inspirado em Paulo Freire. Embora atraente do ponto de vista da proposta, não havia exemplos mostrando as aplicações do Arco como estímulo para outros professores utilizarem a metodologia.

Com o fortalecimento da necessidade de uma perspectiva de ensino mais voltada para a construção do conhecimento pelo aluno, essa alternativa passou a ser considerada nas últimas décadas do século XX, para além das áreas de Agronomia e Enfermagem, alcançando a área da Educação.

Conhecemos, em Londrina, o trabalho do Centro de Ciências da Saúde da UEL, iniciado com o projeto especial de ensino, em 1992, e depois disso as aplicações que vêm sendo feitas por Berbel e colaboradores na área de educação, desde 1994. Das duas experiências, várias publicações têm chegado às bibliotecas das universidades brasileiras e outras 
formas de divulgação têm sido utilizadas, o que tem resultado no conhecimento desses trabalhos em muitos lugares.

No conjunto das disciplinas e atividades de formação do pedagogo, na UEL, os estágios curriculares constituem uma oportunidade de ampliação das relações entre a teoria e a realidade prática da docência e da educação escolar, onde estas se dão.

$\mathrm{O}$ estágio das matérias pedagógicas de magistério de ensino médio - 3 EST 647 - é uma dessas disciplinas que, ao longo de muitos anos, tem estado presente na proposta curricular do curso de Pedagogia, enquanto não se decide o destino da formação do pedagogo, se para atuar como especialista ou para atuar mesmo como professor na educação infantil e nas séries iniciais.

No Estado do Paraná, as escolas profissionalizantes, incluindo as de formação de professores para o magistério nas séries iniciais, sofreram uma grande retração a partir de 1997, quando vários cursos foram desativados, a pretexto de serem reformulados, ocasionando, com isso, a redução do campo de estágio para os alunos de Pedagogia da Instituições de Ensino Superior de Londrina, seja a pública (no caso da UEL), sejam as privadas, como é o caso da Universidade Norte do Paraná e o Centro de Estudos Filadélfia - UNIFIL.

Várias alternativas foram pensadas no Departamento de Educação da UEL, para compensar a lacuna deixada pelo fechamento da maior escola de magistério de ensino médio da cidade.

Em 2004, com o retorno de funcionamento do curso de Magistério do Instituto Estadual de Educação de Londrina - IEEL, algumas professoras do Departamento de Educação passaram a utilizar a estratégia de trabalho aos moldes de uma Iniciação Científica, por meio da Metodologia da Problematização com o Arco de Maguerez.
Esse trabalho proporcionou aos alunos uma experiência com as seguintes características:

1. Partir da observação da realidade de uma sala de aula, durante alguns dias/horas, para a identificação de problemas pedagógicos e a escolha de um deles para o desenvolvimento da investigação.

2. Refletir sobre os possíveis fatores e determinantes maiores do problema eleito e definição dos pontos-chave do estudo.

3. Investigação de cada um dos pontos-chave, buscando informações onde quer que elas se encontrem e analisando-as para se responder ao problema, compondo assim a teorização;

4. Elaboração de hipóteses de solução para o problema.

5. Aplicação de uma ou mais das hipóteses de solução, como um retorno do estudo à realidade investigada.

Com essas atividades e seus desdobramentos, acreditamos que a Metodologia da Problematização com o Arco de Maguerez constitui um rico caminho para estimular o desenvolvimento de saberes diversos pelos seus participantes.

A riqueza dessa metodologia está em suas características e etapas, mobilizadoras de diferentes habilidades intelectuais dos sujeitos, demandando, no entanto, disposição e esforços pelos que a desenvolvem no sentido de seguir sistematizadamente a sua orientação básica, para alcançar os resultados educativos pretendidos.

Situamos, a seguir, uma descrição inicial da Metodologia da Problematização, a partir de informações colhidas nos textos de Bordenave e Pereira (1989) e Berbel (1995, 1996, 1998a, 1998b, 2001 entre outros). 
A metodologia da problematização, suas características gerais e seus usos na UEL

A Metodologia da Problematização com o Arco de Maguerez tem como ponto de partida a realidade que, observada sob diversos ângulos, permite ao estudante ou pesquisador extrair e identificar os problemas ali existentes. O esquema do Arco é o seguinte:

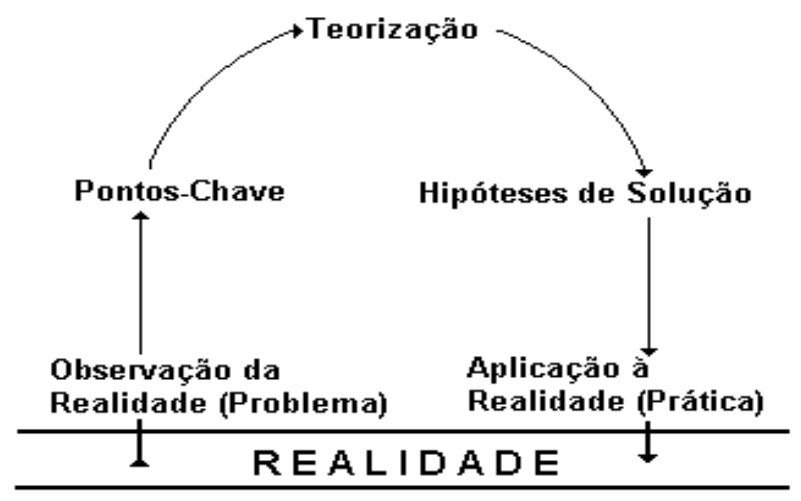

Figura 1. Arco de Maguerez (apud BORDENAVE; PEREIRA, 1989).

O esquema do Arco, utilizado na Metodologia da Problematização, pode ser entendido, quando recorremos à explicação de Bordenave (1989) e a ela associamos a compreensão que Berbel (1998a, 1998b), entre outros títulos, elaborou com a experiência de utilização da Metodologia.

Em síntese, Berbel (1995) explica que o estudo / a pesquisa se dá a partir de um determinado aspecto da realidade. Então, a primeira etapa é a da Observação da realidade e definição do problema. É o início de um processo de apropriação de informações pelos participantes que são levados a observar a realidade em si, com seus próprios olhos, e a identificar-lhes as características, a fim de, mediante os estudos, poderem contribuir para a transformação da realidade observada. Os alunos, apoiados pelo professor, selecionam uma das situações e a problematizam.

Definido o problema a estudar/investigar, inicia-se uma reflexão acerca dos possíveis fatores e determinantes maiores relacionados ao problema, possibilitando uma maior compreensão da complexidade e da multideterminação do mesmo. Tal reflexão culminará na definição dos Pontoschave do estudo, cuja investigação possibilitará uma nova reflexão sobre o mesmo. Os pontoschave podem ser expressos de forma variada: questões básicas que se apresentam para o estudo; afirmações sobre aspectos do problema; tópicos a serem investigados; ou, ainda, por outras formas. Assim, possibilita-se a criatividade e flexibilidade nessa elaboração, após a compreensão do problema pelo grupo.

A terceira etapa - a da Teorização - é o momento de construir respostas mais elaboradas para o problema. Os dados obtidos, registrados e tratados, são analisados e discutidos, buscandose um sentido para eles, tendo sempre em vista o problema. Todo estudo, até a etapa da Teorização, deve servir de base para a transformação da realidade. Então se chega à quarta etapa - a das Hipóteses de Solução -, em que a criatividade e a originalidade devem ser bastante estimuladas para se pensar nas alternativas de solução. Bordenave afirma que "o aluno usa a realidade para aprender com ela, ao mesmo tempo em que se prepara para transformá-la” (BORDENAVE, 1989, p. 25).

Por fim, a última etapa - a da Aplicação à Realidade - é aquela que possibilita o intervir, o exercitar, o manejar situações associadas à solução do problema. A aplicação permite fixar as soluções geradas e contempla o comprometimento do pesquisador para voltar para a mesma realidade, transformando-a em algum grau.

Sendo assim, a Metodologia da Problematização diferencia-se de outras metodologias de mesmo fim, e consiste em problematizar a realidade, em virtude da peculiaridade processual que possui, ou seja, seus pontos de partida e de chegada; efetivase através da aplicação à realidade na qual se observou o problema, ao retornar posteriormente a esta mesma realidade, mas com novas informações 
e conhecimentos, visando à transformação. "Tratase de uma concepção que acredita na educação como uma prática social e não individual ou individualizante" (BERBEL, 1998a, p. 36).

A Metodologia da Problematização dá sua contribuição à educação, ao possibilitar a aplicação à realidade, pois desencadeia uma transformação do real, acentuando o caráter pedagógico na construção de profissionais críticos e participantes. Portanto, “dessa maneira, completa-se o 'Arco' de Maguerez, cujos resultados podem estar sugerindo o reiniciar de muitos outros arcos" (BERBEL, 1995, p. 16). A Metodologia da Problematização passa a ser mais que um método, pelo exercício intelectual e social, que permite enxergar e transformar a realidade com maior criticidade. Como afirma Vasconcellos:

A Metodologia da Problematização parte de uma crítica do ensino tradicional e propõe um tipo de ensino cujas características principais são a problematização da realidade e a busca de solução para problemas detectados, possibilitando assim o desenvolvimento do raciocínio reflexivo e crítico do aluno (VASCONCELLOS, 1999, p. 35).

Com essa orientação e entendimento, a Metodologia da Problematização, após seu início na área da saúde em Londrina, em 1992, vem sendo aplicada na área da educação da UEL em diferentes situações, tais como disciplinas de Didática na graduação e na pós-graduação e em estágios, como caminho metodológico, tanto de ensino quanto de pesquisa. No Programa de Mestrado em Educação, que recebe profissionais de diversas áreas de atuação, interessados em aprofundar-se nas questões do ensino de suas áreas, só nos anos de 1994 a 2000, foram realizados 88 trabalhos com a Metodologia da Problematização (BERBEL, 2001), abrangendo diferentes temas, diferentes níveis de ensino como objeto de estudo, assim como diferentes usos (como ensino, pesquisa, resolução de problemas de trabalho).

Apartirde2002, aMetodologiadaProblematização foi utilizada como caminho de pesquisa para
Dissertações de Mestrado em Educação e também em Dissertações em que foi experimentada no ensino, em áreas diferentes e relatados os seus resultados. Foi também criada uma Disciplina no Programa de Mestrado, em que é trabalhada com os alunos como uma espécie de laboratório.

Os trabalhos produzidos por alunos e pela própria Professora Neusi Berbel têm sido publicados, conforme se lê em www.uel.br/pessoal/berbel/ metodologia_da_problematização, colocando-se à disposição da comunidade acadêmica.

São 15 anos de intensa experiência e produção, constituindo-se uma espécie de linha de pesquisa que busca construir conhecimentos a respeito da teoria $\mathrm{e}$ da prática da Metodologia da Problematização, a cuja produção esta investigação de Iniciação Científica (I.C.) poderá ser agregada, em relação aos saberes que são mobilizados para a formação de professores, com a Metodologia da Problematização.

\section{Saberes de professores, como mais uma referência para compreender o potencial pedagógico da metodologia da problematização}

No contexto das pesquisas educacionais brasileiras, a temática dos saberes de professores tem se mostrado uma área um tanto recente. Essas pesquisas buscam compreender a prática e os saberes pedagógicos e epistemológicos relativos ao conteúdo escolar a ser ensinado e aprendido.

Nunes (2001) apresenta a contribuição de Nóvoa (1995), cuja abordagem veio em oposição aos estudos anteriores, que reduziam a profissão docente a um conjunto de competências e técnicas, gerando uma crise de identidade dos professores em decorrência de uma separação entre o eu profissional e o eu pessoal. Com isso, o professor passou a ser o foco central nos estudos e debates, considerando o quanto o "modo de vida" pessoal acaba por interferir no profissional. Acrescenta ainda o autor, que esse movimento surgiu "num universo pedagógico", 
num amálgama de vontades de produzir um outro tipo de conhecimento, mais próximo das realidades educativas e do cotidiano dos professores (p.19).

A autora se reporta a Pimenta (1999), que identifica o aparecimento da questão dos saberes como um dos aspectos considerados em estudos sobre a identidade da profissão do professor, e salienta:

A identidade do professor é construída a partir da significação social da profissão; da revisão constante dos significados sociais da profissão; da revisão das tradições. Mas também da reafirmação das práticas consagradas culturalmente e que permanecem significativas. Práticas que resistem a inovações porque prenhes de saberes válidos às necessidades da realidade. Do confronto entre as teorias e as práticas, da análise sistemática das práticas à luz das teorias existentes, da construção de novas teorias (PIMENTA, 1999, p. 19).

Dessa forma, resgata a importância de se considerar o professor em sua própria formação, no qual, seus saberes vão-se constituindo a partir de uma reflexão na e sobre a prática.

Por meio de estudos acerca da temática, Nunes (2001) afirma a importância do desenvolvimento de pesquisas, em nossa realidade, que busquem identificar e "analisar os saberes docentes numa perspectiva de contribuir para a ampliação do campo e para a implementação de políticas que envolvam a questão da formação do professor, a partir da ótica dos próprios sujeitos envolvidos" (p. 4).

Em consonância com Tardif(1991), Nunes (2001) afirma que existe a pluralidade e a heterogeneidade do saber docente, destacando a importância dos saberes da experiência que, segundo o autor:

[...] surgem como núcleo vital do saber docente, a partir do qual o(a)s professor(a)s tentam transformar suas relações de exterioridade com os saberes em relações de interioridade com sua própria prática. Nesse sentido os saberes da experiência não são saberes como os demais, eles são, ao contrário, formados de todos os demais, porém retraduzidos, "polidos" e submetidos às certezas construídas na prática e no vivido (TARDIF 1991, p.234 apud NUNES, 2001, p. 4).

Outro pesquisador, Borges (1995), mencionado por Nunes (2001), propõe que "talvez se possa pensar que a valorização dos saberes da experiência, dos saberes de professores de um modo geral, seja uma alternativa no sentido de buscar uma maior aproximação da formação acadêmica com a realidade escolar" (p. 14). Isso levaria a estreitar os vínculos na relação entre teoria e prática.

Nesse contexto, buscar entender como se configuram os saberes de professores, por meio da Metodologia da Problematização, exige uma reflexão acerca da noção de saber.

Apesar de algumas diferenças entre os autores que lidam com esse tema, optamos em adotar as contribuições de Tardif (2002), segundo o qual, a noção de saber compreende "os conhecimentos, as competências, as habilidades e as atitudes dos docentes", ou seja, aquilo que foi muitas vezes chamado de saber, saber-fazer e de saber-ser. O autor valida essa afirmação quando a associa ao saber do professor, e acrescenta que essa não é algo que flutue no espaço:

O saber dos professores é o saber deles, com a sua experiência de vida e com a sua história profissional, com as suas relações com os alunos em sala de aula e com os outros atores escolares [...] por isso, é necessário estudá-lo relacionando-o com esses elementos constitutivos do trabalho docente (TARDIF, 2002, p. 11).

Desse modo, o saber dos professores é um saber social, pois não trabalha apenas um objeto, ele trabalha com sujeitos, buscando transformar os alunos, educá-los, ou seja, “o saber, não é uma substância ou um conteúdo fechado em si mesmo, ele se manifesta através de relações complexas entre professor e seus alunos" (p.13).

Tal posição do autor advém de pesquisas com professores, em que estes se referem aos diferentes saberes ligados ao seu trabalho. $\mathrm{O}$ autor afirma que 
"os saberes que servem de base para o ensino [...] não se limitam a conteúdos bem circunstanciados que dependem de um conhecimento especializado e abrangem grande diversidade de objetos, de questões, de problemas que estão todos relacionados com seu trabalho" (TARDIF, 2002, p. 61).

Para o autor, os saberes, em geral, são plurais, heterogêneos, temporais e localizados por um padrão de normas relativas à profissão de professor, o que é diretamente proporcional à construção identitária dessa profissão. Acreditando nessa premissa, diríamos que os saberes estão relacionados ao trabalho do professor, e são saberes sobre o trabalho, no trabalho e para o trabalho.

Tardif (2002) classifica essa pluralidade de saberes de professores em:

Saberes docentes: "saber plural, formado pelo amálgama, mais ou menos coerente, de saberes oriundos da formação profissional e de saberes disciplinares, curriculares e experienciais" (p. 36). Tardif (2002) coloca em evidência sua própria perspectiva teórica a respeito desses saberes, pois “a questão do saber dos docentes não pode ser separada das outras dimensões do ensino, nem do estudo do trabalho realizado diariamente pelos professores de profissão, de maneira mais específica" (p.10). O autor defende que "um professor nunca define sozinho e em si mesmo o seu próprio saber profissional. Ao contrário, esse saber é produzido socialmente, resulta de uma negociação entre diversos grupos" (p.13). Nessa perspectiva, segundo o autor, o saber dos professores parece estar assentado em relações constantes entre o que eles são (incluindo emoções, a cognição, as expectativas, etc.) e o que fazem.

Saberes Profissionais: "conjunto de saberes transmitidos pelas instituições de formação de professores" (p.36). Pode-se se dizer que a relação do professor com os seus próprios saberes é acompanhada de uma relação social, que pode ser transmitida pela família, escola, igreja e que implica uma relação social com esses mesmos saberes, bem como com os grupos e indivíduos que os produzem.
"O saber é um constructo social produzido pela racionalidade concreta dos atores, por suas deliberações, racionalizações e motivações que constituem a fonte de seus julgamentos, escolhas e decisões" (TARDIF, 2002, p.222). Essas relações de exterioridade inserem-se numa divisão social do trabalho intelectual entre os produtores de saberes e os formadores, entre os grupos e instituições responsáveis pelas tarefas de formação.

Saberes pedagógicos: que "apresentam-se como doutrinas ou concepções provenientes de reflexões sobre a prática educativa no sentido amplo do termo; reflexões racionais e normativas que conduzem a sistemas mais ou menos coerentes de representação e orientação das atividades educativas" (p.37). Os saberes pedagógicos são incorporados à formação do professor, que decide se vai utilizar, por exemplo, de correntes pedagógicas como escola nova, a histórico-crítica, entre outras. Essas doutrinas fornecem-lhe uma forma de pensar, uma ideologia, técnicas de ensino compatíveis etc..

Saberes da disciplina: "correspondem aos diversos campos do conhecimento, e se encontram hoje integrados nas universidades, sob a forma de disciplinas que emergem da tradição cultural e dos grupos sociais produtores de saberes" (p.38). Segundo Tardif (2002), estes saberes integram-se na prática docente por meio das disciplinas oferecidas nos cursos de formação de professores que correspondem e abrangem diversos conhecimentos dos quais dispõe nossa sociedade.

Saberes curriculares: "correspondem aos discursos, objetivos, conteúdos e métodos a partir dos quais a instituição escolar categoriza e apresenta os saberes sociais por ela definidos e/ou selecionados como modelos da cultura erudita e de formação para a cultura erudita" (TARDIF, 2002, p.38). Esses saberes apresentam-se sob a forma de programas escolares que os professores devem aprender, mas não se limitam a eles, pois segundo o autor, "o saber não é uma substância ou um conteúdo fechado em si mesmo, ele se manifesta através de 
relações complexas entre professor e seus alunos" (p.13). Como explica o autor,

A Pedagogia, a Didática, a Aprendizagem e o Ensino são construções sociais, cujos conteúdos, formas e modalidades dependem intimamente da história de uma sociedade [...] de seus poderes e contrapoderes, das hierarquias que predominam na educação formal e informal (TARDIF, 2002, p. 14).

Saberes experienciais: "saberes que os professores, no exercício de suas funções e na prática de sua profissão desenvolvem, baseados em seu trabalho cotidiano e no reconhecimento de seu meio. [...] Esses saberes brotam da experiência e são por ela validados" (p.39). A formação crítica e reflexiva do professor envolve sua vida e o seu saber pedagógico, o qual o professor constrói no cotidiano de seu trabalho e que sustenta a sua ação docente. Os saberes experienciais surgem como núcleo vital do saber docente, a partir do qual os professores buscam transformar suas relações de exterioridade com os saberes em relações de interioridade com sua própria prática. Nesse sentido, os saberes experienciais são formados de todos os demais, mas "retraduzidos, polidos" e submetidos às certezas construídas na prática e na experiência, sendo fundamentais para a construção da identidade do professor.

Saberes temporais: "o tempo é um fator importante na edificação dos saberes que servem de base ao trabalho docente", pois os professores adquiriram os saberes através de processos de aprendizagem e de socialização, que atravessaram tanto a história de vida quanto a carreira. Antes mesmo de começarem a ensinar, os professores já sabem, de muitas maneiras, o que é ensino, por causa de toda sua história escolar anterior. Essa idéia de temporalidade não se limita à história escolar, pois também se aplica diretamente a sua carreira, marcada pela construção do saber profissional.

Mediante esses saberes citados, as considerações de Tardif (2002) vêm comprovar que os saberes de professores constituem um saber social. Desse modo, o professor se serve de sua cultura pessoal, que provêm de sua história de vida e de sua cultura escolar anterior e atual - conhecimentos esses adquiridos na universidade, assim como em certos conhecimentos didáticos e pedagógicos trabalhando com sujeitos, visando educá-los para atuarem na sociedade.

Segundo o autor, "as múltiplas articulações entre a prática docente e os saberes, fazem dos professores um grupo social e profissional cuja existência depende, em grande parte, de sua capacidade de dominar, integrar e mobilizar tais saberes enquanto condições para a sua prática" (TARDIF, 2002, p. 39). Afirma que o profissional, sua prática e seus saberes não são entidades separadas, mas 'copertencem' a uma situação de trabalho na qual 'coevoluem' e se transformam (TARDIF, 2002, p.257). Ou seja, querer estudar os saberes de professores sem associá-los ao ensino, seria um equívoco.

Essa pluralidade apresentada, que constitui as diferentes categorias de saberes de professores, muitos deles adquiridos/desenvolvidos a partir da escola, pode ser observada num modelo tipológico que o autor elaborou, juntamente com Raymond (2002, p.63). Para identificar e classificar esses saberes, tomam como critério a relação dos mesmos com os lugares nos quais os próprios professores atuam, com as organizações que os formam e/ou nas quais trabalham, com seus instrumentos de trabalho e com sua experiência de trabalho.

Os saberes desse modelo são os seguintes:

1. Os saberes pessoais dos professores;

2. Os saberes provenientes da formação escolar anterior;

3. Os saberes provenientes da formação profissional para o magistério;

4. Os saberes provenientes dos programas e livros didáticos usados no trabalho;

5. Os saberes provenientes de sua própria experiência na profissão, na sala de aula e na escola. 
Pinto (2003) traz outras contribuições quando se refere à experiência, afirmando que em certa consonância Tardif, Pimenta e Anastasiou propõem que é a demanda da prática que vai configurar os saberes. E que,

[...] nos processos de formação de professores, é preciso considerar a importância dos saberes das áreas de conhecimento (ninguém ensina o que não sabe), dos saberes pedagógicos (pois o ensinar é uma prática educativa que tem diferentes e diversas direções de sentido na formação do humano), dos saberes didáticos (que tratam da articulação da teoria da educação e da teoria de ensino para ensinar nas situações contextualizadas) e dos saberes $d a$ experiência do sujeito professor (que dizem do modo como nos apropriamos do ser professor em nossa vida) (TARDIF, 2002, p. 71 apud PINTO, 2003, p. 03).

Outro aspecto a considerar está na temporalidade dos saberes. O autor afirma que o professor se baseia em sua "experiência vivida enquanto fonte viva de sentidos a partir da qual o próprio passado lhe possibilita esclarecer o presente e antecipar o futuro" (p.66). E, em outro momento, valida essa afirmação, dizendo que "os saberes dos professores são temporais, pois utilizam e se desenvolvem no âmbito de uma carreira" (p.70), isto é, ao longo de um processo temporal de vida profissional. Portanto, para Tardif, a inscrição no tempo é "particularmente importante para compreender a genealogia dos saberes docentes" (2002, p. 67).

Salientamos também que os saberes constitutivos da profissão de professor, independente do nível de atuação, começam antes e apesar de qualquer formação inicial institucionalizada. Aprendemos uma série de conjuntos de valores, mesmo profissionais, que nos permitem construir uma representação sobre o que é ser professor. Ao sermos autorizados por nossos pares a desempenhar a profissão docente, devemos transitar entre valores já instituídos, os quais devemos incorporar e ou até modificar.

Em Pimenta (1999), encontramos a idéia de que é primordial ressignificar os processos formativos a partir da reconsideração dos saberes necessários à docência, colocando a prática pedagógica e docente escolar como objeto de análise. Segundo a autora, do confronto entre as teorias e as práticas, constróise o significado de cada professor, enquanto ator e autor, a partir de seus valores, sua história de vida e de seus saberes.

A autora inclui, entre os saberes da docência, aqueles relacionados à experiência, ao conhecimento e ao saberes pedagógicos. E em relação aos saberes da experiência, explica-os como sendo parte de um processo primordial para a construção da identidade do professor e sua reflexão sobre a prática.

Já em relação ao conhecimento, Pimenta (1999) apoia-se em Edgar Morin para justificar que o conhecimento não se reduz à informação. Este é um primeiro estágio daquele. Conhecer implica um segundo estágio: o de trabalhar com as informações classificando-as, analisando-as e contextualizando-as.

O terceiro estágio tem a ver com a inteligência, a consciência ou sabedoria. Inteligência tem a ver com a arte de vincular conhecimento de maneira útil e pertinente, isto é, de produzir novas formas de progresso e desenvolvimento: consciência e sabedoria envolvem reflexão, isto é, capacidade de produzir novas formas de existência, de humanização. E é nessa trama que se pode entender as relações entre conhecimento e poder. $\mathrm{O}$ acesso à informação nem sempre se dá por todos os cidadãos, portanto, não basta produzir conhecimento, mas é preciso produzir as condições de produção do conhecimento.

A educação, para Pimenta (1999), é um processo de humanização. Educar na escola, segundo a autora, requer preparação científica, técnica e social. A educação escolar na sociedade tecnológica, multimidiática e globalizada, tem que possibilitar que os alunos trabalhem os conhecimentos científicos e tecnológicos, desenvolvendo habilidades para operálos, revê-los e reconstruí-los com sabedoria. Isso implica analisá-los, confrontá-los e contextualizálos, permitindo aos alunos construírem a noção de cidadania. 
Quanto aos saberes pedagógicos, afirma a autora que estes são indissociáveis da didática. Esses saberes, no decorrer da história, têm sido trabalhados por professores em blocos distintos e desarticulados. Há uma época em que houve o predomínio dos saberes pedagógicos, em que se salientavam os temas do relacionamento professoraluno, da importância da motivação e do interesse no processo de aprendizagem, das técnicas de ensinar. Há outra época da pedagogia, baseada na ciência psicológica, em que se constituiu uma Psicopedagogia que, então, se transformou em uma tecnologia. Em outras épocas, assumiram poder os saberes científicos, como a importância da didática das disciplinas, sendo fundamental no ensino os saberes científicos.

A fragmentação dos saberes e a flutuação da Pedagogia enquanto ciência, ao restringir-se ao campo aplicado das demais ciências da educação, perdeu seu significado de ciência prática da prática educacional. Houssaye, apud Pimenta (1999), aponta como caminho de superação, que nos empenhemos em construir os saberes pedagógicos a partir das necessidades pedagógicas posta pelo real. Trata-se de reinventar os saberes pedagógicos a partir de uma prática social da educação.

Superar a tradicional fragmentação dos saberes da docência e considerar a prática social como ponto de partida e como ponto de chegada, possibilitará uma ressignificação dos saberes na formação de professores. O futuro profissional não pode construir seu saber-fazer senão a partir de seu próprio fazer. Em contato com os saberes da educação e aqueles relacionados com a pedagogia, os profissionais da educação podem encontrar instrumentos necessários para se interrogarem e alimentarem suas práticas, confrontando-os. É aí que se produzem saberes pedagógicos, na ação.

É também preciso construir um significado epistemológico à prática pedagógica, pois os elementos da prática docente estão voltados para a reflexão dos resultados. Os saberes pedagógicos se formam mobilizados a partir dos problemas que a prática coloca, entendendo, pois, a dependência da teoria em relação à prática, pois esta lhe é anterior.

Deacordo com os autores mencionados, épossível perceber que o saber é considerado resultado de uma produção social, de uma interação entre sujeitos, e que os saberes de professores sempre estiveram presentes em sua atuação, mas que por algum tempo não eram priorizados.

Diante deste percurso, pode-se compreender que, ao pensar um modelo de professor, deve-se levar em conta o contexto no qual se constroem e se aplicam os saberes docentes, ou seja, as condições históricas e sociais nas quais se exerce a profissão, que é também influenciada por questões culturais e pessoais.

Com base nessas reflexões, parece evidente que toda profissão é um constructo social e, como tal, atende a algumas exigências de um dado contexto histórico, bem como contém uma concepção do próprio ator profissional sobre o que constitui sua profissão.

Tomando a Metodologia da Problematização como referência, buscamos nesta pesquisa, por meio de autores que tratam de saberes, identificar que saberes podem ser mobilizados/estimulados quando se a utiliza, sabendo de antemão que a formação crítica e reflexiva do professor envolve sua vida e o seu saber pedagógico, o qual o professor constrói no cotidiano de seu trabalho e que sustenta a sua ação docente, para a qual a prática se faz necessária.

Acreditamos que a escola (a sala de aula) é o local onde a ação docente manifesta-se de maneira mais evidente, podendo contribuir no processo de construção do aluno crítico, daí a essência da pesquisa, a de unir esses saberes com a Metodologia da Problematização, que possui um grande potencial pedagógico.

Mediante essas afirmações, apresentamos, no próximo item, uma síntese das ações contidas nas etapas da Metodologia da Problematização com o arco de Maguerez, para, na seqüência, relacioná-las com os saberes que as envolvem. 
Síntese das ações contidas nas cinco etapas da metodologia da problematização, com o arco de Maguerez

\section{Observação da realidade (problema)}

Ao utilizarmos da Metodologia da Problematização, com o Arco de Maguerez, inicialmente buscamos identificar o recorte de realidade a ser observado, para desencadear o processo, por meio das cinco etapas do Arco.

Quando nos aproximamos dessa realidade, já possuímos alguns saberes, que englobam conhecimentos, crenças, competências, habilidades, que são incorporados e adquiridos de fontes diversas (história de vida, na escola, experiência do trabalho etc.), tendo construído assim um saber existencial.

O sujeito, perante a etapa, envolvido por esses saberes, elege um recorte dessa realidade, e decide qual a forma de observação (técnicas e/ou instrumentos) que vai utilizar. Vale aqui ressaltar que se o trabalho for em grupo, o grupo é responsável por essas ações. Por outro lado, se o trabalho tem origem numa disciplina em que o professor define a unidade de ensino, o foco maior estará decidido pelo professor, mas não o objeto específico, que resultará da problematização do foco pelo grupo. No caso, ainda, de uma pesquisa por alunos, o foco maior deverá estar de acordo com a linha de pesquisa do orientador. Conseqüentemente, ao observar esse recorte, o sujeito percebe que depende de um conhecimento mais especializado (saber científico), que perpassa seus conhecimentos prévios, além das suas expectativas, seu entusiasmo e então, define os formatos possíveis para a realização dessa observação.

Ao se apropriar das informações advindas da realidade, o sujeito as registra para analisálas, constituindo-se um meio privilegiado de problematizar a realidade, confrontando essas novas informações com os seus saberes experienciais, o que lhe permite problematizar essa realidade. É desse modo que os saberes do sujeito, quando trabalha em grupo, são compartilhados, colocados em dúvida, e novos saberes são construídos em interação com os outros. Por meio desse processo, dessa interação, o olhar do sujeito não é mais o mesmo, pois implica uma relação social com esses mesmos saberes, bem como com os outros sujeitos que os produzem, construindo uma nova perspectiva perante o recorte analisado.

Nesse momento, o sujeito, ao realizar a observação, verifica se existem aspectos em comum e/ou contraditórios em relação aos seus saberes e questionamentos, visando escolher um, a partir de um critério determinado, pois a realidade educacional e social é muito rica em problemas ou aspectos a serem estudados. Então, elege um dos problemas com critério (como por exemplo, o que pode ter mais urgência, prioridade, necessidade de estudo, que possibilite atuar sobre ele etc.).

Definido(s) o(s) critério(s), éo momento de eleger o foco específico, bem como redigir o problema, almejando o seu estudo e possíveis transformações no recorte observado. Na redação do problema, é preciso situar o cerne do questionamento para o qual se buscará uma resposta ou solução. É sempre interessante justificar a escolha do problema, por meio de explicações quanto à importância de se fazer o estudo, das possíveis contribuições para o estudante e para o meio estudado, bem como para a área de pesquisa, como previsões do que vai ser possível contribuir com ele.

Portanto, já na primeira etapa, é possibilitado ao participante, intencionalmente, desenvolver uma postura crítica em relação à realidade, bem como a construção de uma postura diante do estudo, proporcionando um envolvimento intelectual, emocional e político ao longo das etapas do Arco de Maguerez, por um processo de reflexão que exige esforços de quem escolhe utilizar a Metodologia.

Sintetizamos, a seguir, as ações que correspondem a esta etapa. 


\begin{tabular}{|c|l|}
\hline Etapa & Ações relativas à 1 $\mathbf{1}^{\text {a }}$ etapa da M. P. com o Arco de Maguerez \\
\hline \multirow{3}{*}{ 1. Observação da Realidade (Problema) } & * Identifica o recorte de realidade a ser observado \\
& * Elege a forma de observação \\
& * Registra a observação (no formato definido ou possível) \\
& * Analisa o registrado, em seu conteúdo, problematizando-o \\
& * Elege o foco do estudo a partir de um critério \\
& * Redige o problema \\
& * Justifica a escolha do problema \\
\hline
\end{tabular}

Quadro 1. Ações relativas à Observação da Realidade

Com a compreensão das ações da etapa Observação da Realidade e definição do problema, passamos a seguir para a segunda etapa do Arco.

\section{Pontos-chave}

Afirma Berbel (1999, p. 4) que a etapa dos pontoschave "estimula um momento de síntese após a análise inicial que foi feita, é o momento da definição do que vai ser estudado sobre o problema [...] a fim de se buscar uma resposta para esse problema". Para estabelecer os pontos-chave, inicia-se por uma reflexão (síncrese) a respeito do problema para compreendê-lo melhor. Primeiro, pela identificação de alguns possíveis fatores associados ao problema, como o que estaria ocasionando a existência do problema, de forma mais direta, naquele recorte de realidade.

Num segundo momento, a reflexão toma como foco os possíveis determinantes maiores do problema. São aspectos da vida em sociedade que, de modo indireto, podem influenciar sobre o problema e os próprios fatores já mencionados. São, em geral, aspectos contextuais como políticos, econômicos, éticos, filosóficos, envolvendo valores etc.. O participante, ao realizar essa etapa, descreve de forma clara toda a reflexão, com as várias possíveis explicações do problema, percebendo que, em geral, é complexo e multideterminado.

Segundo Berbel (1999, p. 4), “é com estas reflexões que os alunos são levados a levantar, ou definir, com os conhecimentos que têm naquele momento inicial do seu estudo, alguns pontos a estudar", ou seja, a eleger, com critérios, aqueles aspectos que serão estudados na etapa seguinte, os considerados prioritários ou mais relevantes para esclarecer ou solucionar o problema.

Definidos os pontos-chave, os participantes redigem toda essa reflexão, extraindo o seu sentido para o estudo, pelas possíveis explicações da existência do problema. Os pontos-chave podem ser expressos por meio de questões básicas que se apresentam para o estudo, afirmações fundamentais sobre aspectos do problema, um conjunto de tópicos a serem investigados, ou outras formas, "o que possibilita criatividade e flexibilidade ao tratamento do problema pelo grupo" (BERBEL, 1995, p. 15).

Sintetizamos a seguir as ações que correspondem a esta etapa. 


\begin{tabular}{|c|c|}
\hline Etapa & Ações relativas à $2^{\mathrm{a}}$ etapa da $\mathrm{M}$. P. com o Arco de Maguerez \\
\hline 2. Pontos-chave & $\begin{array}{l}\text { * Reflete a respeito do problema } \\
\text { - Identifica possíveis fatores associados ao problema } \\
\text { - Identifica possíveis determinantes maiores do problema } \\
\text { - Redige toda essa reflexão, extraindo o seu sentido para o estudo, pelas } \\
\text { - possíveis explicações da existência do problema } \\
\text { * Elege, com critérios, aqueles aspectos que serão estudados na etapa seguinte } \\
\text { * Redige os pontos-chave }\end{array}$ \\
\hline
\end{tabular}

Quadro 2. Ações relativas aos Pontos-chave

Com a compreensão das ações das etapas Observação da Realidade e Pontos-chave, seguimos para a terceira etapa do Arco.

\section{Teorização}

Ao eleger a forma de estudar cada ponto-chave, ou seja, a metodologia - forma específica de estudo, conforme a natureza de cada aspecto eleito, iniciase a investigação.

Essa etapa proporciona um aprofundamento dos saberes prévios do(s) sujeito(s) a respeito do problema, elencados na etapa dos Pontos-chave. Ou seja: "a Teorização vai ser o momento da investigação, do estudo propriamente dito, daqueles pontos-chave definidos para esclarecer o problema" (BERBEL, 1999, p. 4).

A etapa permite construir respostas apoiadas na literatura, por meio de informações de especialistas, pesquisas de cunho histórico, técnico e científico e também, por informações de pessoas que vivem o problema. Assim, após definir o caminho de investigação, inicia-se pela preparação dos instrumentos de coleta de informações. Os mesmos são testados e aperfeiçoados, para um bom encaminhamento das atividades, assim como são definidas a organização e as condições para a aplicação dos instrumentos.
Coletadas as informações (aplicação dos procedimentos e instrumentos definidos), seja na biblioteca, pela internet, junto às pessoas, em documentos, etc., elas são tratadas, discutidas e analisadas, buscando-se um sentido para elas, relacionando teoria e prática, sempre com vistas à compreensão e solução do problema. Nesse momento, os participantes têm a oportunidade de confrontar o estudo realizado com as hipóteses explicativas iniciais, verificando se elas foram confirmadas, contrariadas ou se sequer foram consideradas na Teorização. Ou seja, verificam se há relações entre as diferentes informações, para chegar à conclusão das mesmas, em função do problema.

Esse processo de reflexão possibilita uma aquisição de novos conhecimentos (saberes). "É possível às pessoas que estão estudando rever as suas posições e aprofundar conhecimentos, ter uma consciência muito maior daquele problema e de sua influência sobre o meio social" (BERBEL, 1999, p. 5).

Vale citar que, durante a Teorização, há a oportunidade de alterações em relação aos pontoschave definidos na etapa anterior, caso se constate a necessidade de mais algum tópico ou da redundância de algum dos já definidos. As condições gerais dos participantes e da realização é que definem a necessidade de delimitação de cada estudo. 
Após o aprofundamento do conhecimento, ao olhar de diversos ângulos o mesmo foco, ao refletir sobre os pontos-chave (suas indagações iniciais), realizando algumas comparações, o sujeito registra toda a teorização. Todo o estudo deve servir de base para a transformação da realidade, pois o sujeito deve sempre analisar cada ponto-chave tendo em vista o problema, visando transformar a parcela dessa realidade que foi eleita para o estudo.

Sintetizamos a seguir as ações que correspondem a esta etapa.

\begin{tabular}{|c|c|}
\hline Etapa & Ações relativas à $3^{\text {a }}$ etapa da M. P. com o Arco de Maguerez \\
\hline 3. Teorização & $\begin{array}{l}\text { * Elege a forma de estudar cada ponto-chave } \\
\text { * Prepara os instrumentos de coleta de informação } \\
\text { * Testa os instrumentos } \\
\text { * Organiza as condições para a aplicação dos instrumentos } \\
\text { * Coleta as informações (aplicação dos procedimentos e instrumentos definidos } \\
\text { * Trata as informações } \\
\text { * Analisa e discute as informações } \\
\text { • Estabelece relações entre as diferentes informações } \\
\text { * Conclui em função do problema, verificando se as hipóteses explicativas iniciais foram } \\
\text { confirmadas, negadas ou não foram consideradas na Teorização } \\
\text { * Registra toda a Teorização }\end{array}$ \\
\hline
\end{tabular}

Quadro 3. Ações relativas à Teorização.

Damos continuidade à compreensão das ações das etapas, analisando a seguir a quarta etapa do Arco.

\section{Hipóteses de solução}

Segundo Berbel (1999, p. 5-6), a quarta etapa "deve ser bastante criativa. Essa criatividade deve ser estimulada" para que o processo percorrido até esse momento "supere os conhecimentos e as ações anteriores" que visam à realização de alguma mudança daquela parcela da realidade estudada.

Ao estabelecer relações entre as diferentes informações teorizadas e com base nas reflexões realizadas nas etapas anteriores, elaboram-se as hipóteses de solução para o problema, tendo em vista o recorte da realidade. As hipóteses podem abranger diferentes instâncias ou níveis de ação.

Afirma Berbel (2007, p. 4) que "essa etapa é muito rica, por mobilizar mais uma vez o potencial reflexivo e criativo dos participantes, incluindo operações mentais de alto nível (que ultrapassam a simples retenção de informações na memória)".

Ao registrar todas as hipóteses de solução para todas as instâncias com ele [o problema] envolvidas -, os participantes devem explicar e ou argumentar o sentido das mesmas. Nesse momento, os participantes são capazes de projetarem idéias que poderão vir a se transformar em ações concretas para solucionar ou dar passos no caminho da solução para o problema estudado.

Sintetizamos a seguir as ações que correspondem a esta etapa. 


\begin{tabular}{|l|l|}
\hline \multicolumn{1}{|c|}{ Etapa } & \multicolumn{1}{|c|}{ Ações relativas à 4 etapa da M. P. com o Arco de Maguerez } \\
\hline \multirow{2}{*}{ 4. Hipóteses de Solução } & $\begin{array}{l}\text { * Elabora as hipóteses de solução para o problema, com base na Teorização e etapas } \\
\text { anteriores } \\
\text { * Abrange diferentes instâncias ou níveis de ação visando à transformação daquela } \\
\text { parcela de realidade estudada } \\
\text { * Usa criatividade para encontrar ações novas } \\
\text { * Explica/argumenta as hipóteses elaboradas } \\
\text { * Registra toda a elaboração }\end{array}$ \\
\hline
\end{tabular}

Quadro 4. Ações relativas às Hipóteses de Solução.

Por fim, após a compreensão das ações das etapas anteriores, analisamos a quinta etapa do Arco.

\section{Aplicação à realidade (prática)}

Nessa etapa, os participantes analisam a aplicabilidade das hipóteses, as que poderão vir a ser transformadas em ações concretas na realidade de onde foi extraído o problema.

A finalidade maior desta etapa é promover, a partir das hipóteses já elaboradas, "uma transformação, mesmo que pequena, naquela parcela de realidade" (BERBEL, 1999, p. 6). As hipóteses passarão, portanto, por uma análise dos participantes, para verificar a exeqüibilidade, a urgência, a prioridade, etc., visando eleger aquelas que poderão ser realizadas e atingir mais diretamente o problema, contribuindo para a transformação da realidade estudada.

Após tal escolha, inicia-se um processo de planejamento e execução das ações com as quais os participantes se comprometem. Berbel reforça que "essa etapa da Metodologia da Problematização não é um mero exercício intelectual, pois as decisões tomadas deverão ser executadas ou encaminhadas" (2007, p. 4).

A aplicação das hipóteses na realidade prática envolve os participantes com o meio, proporcionando o desenvolvimento de um compromisso social. Prossegue afirmando a autora que "esse exercício final da Metodologia da Problematização antecede uma ação concreta dos participantes, que são também cidadãos que se preparam para uma atuação social (profissional, política, familiar etc.) cada vez mais informada e mais consciente" (BERBEL, 2007, p. 4).

Esta etapa proporciona aos participantes, por meio de todo o estudo realizado, uma nova contribuição para ampliar seus conhecimentos sobre a realidade estudada. Desse modo, contribui para que os mesmos se percebam nesse processo como agentes ativos de sua transformação, preparandose para uma prática efetiva, ou seja, o exercício da cidadania.

Registrado todo o processo, os participantes percebem que a M.P. diferencia-se de outras metodologias de características problematizadoras no seguinte sentido: além de consistir em problematizar a realidade, seu ponto de partida efetiva-se por meio da aproximação e conhecimento da realidade na qual se observou o problema, e como ponto de chegada, retorna a esta mesma realidade, mas com novas informações e conhecimentos que permitem algum grau de transformação.

Completa-se, assim, o Arco de Maguerez, que pode dar origem a uma série de outros arcos, pelas descobertas e novas indagações que vão ocorrendo.

Sintetizamos a seguir as ações que correspondem a esta etapa. 


\begin{tabular}{|c|c|}
\hline Etapa & Ações relativas à $5^{\text {a }}$ etapa da M. P. com o Arco de Maguerez \\
\hline $\begin{array}{l}\text { 5. Aplicação à Realidade } \\
\text { (prática) }\end{array}$ & $\begin{array}{l}\text { *Analisa a aplicabilidade das hipóteses } \\
\text { *Elege, com critérios (exeqüibilidade, urgência, prioridade etc.) as que } \\
\text { julga poder colocar em prática } \\
\text { * Planeja a execução das ações pelas quais se compromete } \\
\text { *Coloca-as em prática } \\
\text { * Registra todo o processo, analisando os resultados, quando possível. }\end{array}$ \\
\hline
\end{tabular}

Quadro 5. Ações relativas à Aplicação à Realidade (prática).

Em síntese, o retorno à realidade significa, para o participante, uma prática consciente, informada e intencionalmente transformadora.

A Metodologia da Problematização estimula, portanto, aos participantes que a utilizam, o despertar da consciência crítica, política, bem como o comprometimento com a sociedade, no sentido de vir a transformá-la em algum grau, sendo, por isso, um caminho primordial para o exercício da cidadania.

Esse caráter transformador da M.P., refletindo o seu grande potencial metodológico e educacional, dá-se por meio de sua proposta que se coloca como mediadora entre a teoria e a prática. Em síntese, o processo de ação (prática) - reflexão (teórico-prática) - preparando para nova ação, leva o participante a desenvolver um compromisso com a práxis. Seu potencial, portanto, prepara o cidadão para atuações futuras com desafios cada vez mais complexos.

Concluímos, pelo exposto acima, que é possível afirmar que o participante da Metodologia da Problematização, ao desenvolver as cinco etapas do Arco de Maguerez, envolve-se numa ação pedagógica de transformação e não de adaptação, possibilitando um olhar cada vez mais crítico para atuar na realidade social.

Em termos educacionais, essa metodologia tem um potencial pedagógico que pode auxiliar no processo de transformação do ser humano, provocando a superação da sua "acomodação", levando-o a intervir de forma ativa na realidade.

A Metodologia da Problematização como um todo nos impõe o conhecimento crítico da realidade, proporcionando o exercício da práxis, que inclui ação - reflexão - nova ação (intencionalmente transformadora). Trata-se de um caminho de ensino e de pesquisa efetivo na prática pedagógica, cuja essência é a dialogicidade, a desalienação e a curiosidade como prática libertadora, como recomendou Paulo Freire.

Para atingir um dos objetivos da pesquisa acerca da temática dos saberes, apresentamos a seguir, os diferentes tipos de saberes associados às ações referentes às cinco etapas da Metodologia da Problematização, com o arco de Maguerez. Buscamos estabelecer a relação que percebemos entre as contribuições sobre os saberes de professores e as características da Metodologia da Problematização, visando identificar o potencial dessa metodologia sob esse ponto de vista, conscientes de que os participantes do estudo ou investigação podem ser alunos (futuro professores) ou professores (em processo de formação continuada), ou ainda pesquisadores. 


\section{Saberes associados às ações da metodologia da problematização}

Neste item, buscamos estabelecer a relação entre as contribuições a respeito dos saberes de professores e as características da Metodologia da Problematização, buscando identificar o potencial dessa metodologia sob esse ponto de vista, tal como anunciado no terceiro objetivo para este estudo. Fazemos isso, etapa por etapa, de modo a tornar bastante evidente o que conseguimos elaborar até este momento como conseqüência da nossa compreensão sobre a temática da Metodologia da Problematização e dos saberes de professores.

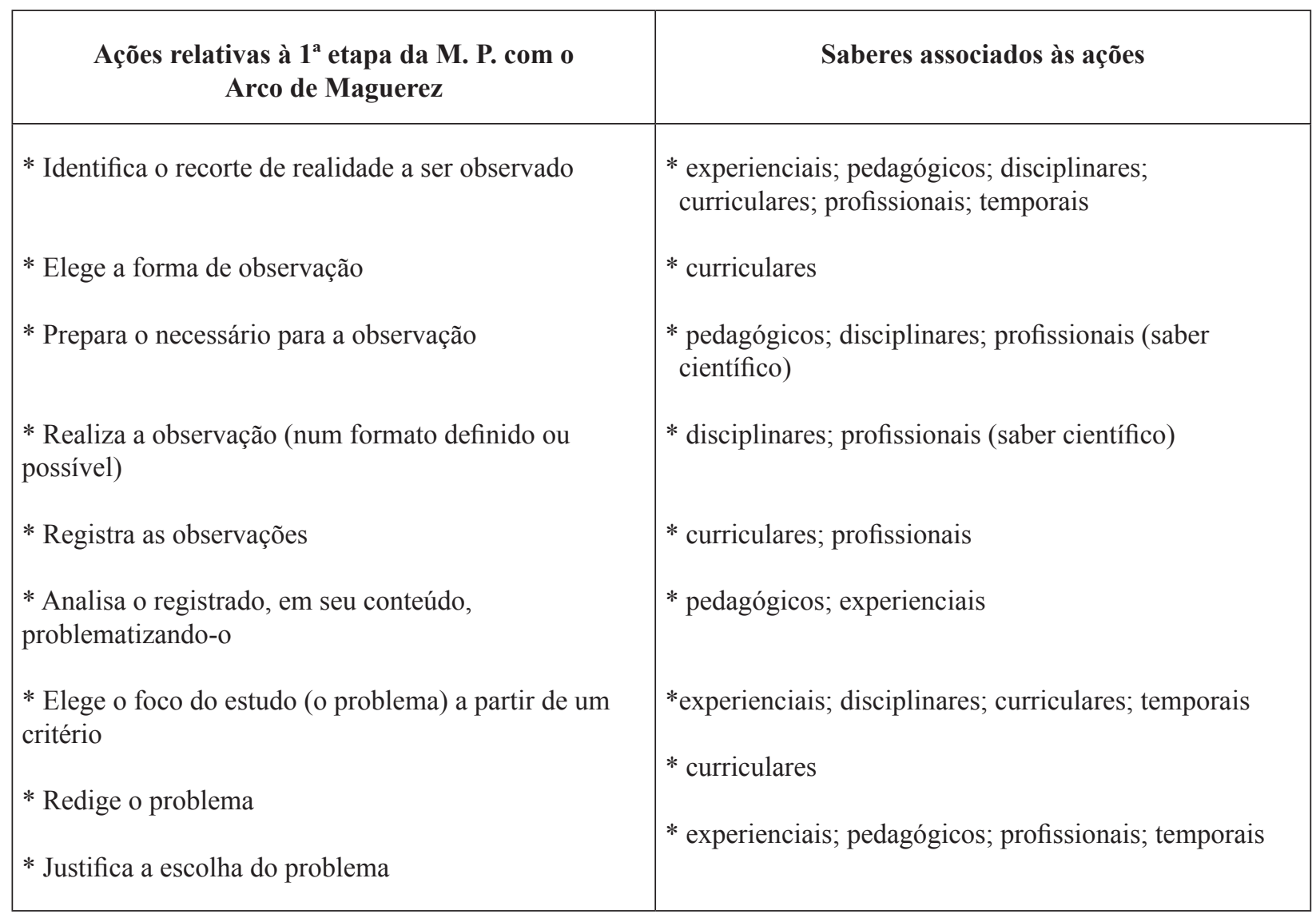

Quadro 6. Saberes associados às ações da etapa Observação da realidade.

Elegemos três ações dessa etapa para demonstrar a nossa análise dos saberes que a permeiam. Pudemos observar na ação de identificar o recorte de realidade a ser observado, que nesse momento, é mobilizado um misto de saberes já existentes (experienciais; pedagógicos; disciplinares; curriculares; profissionais; temporais) advindos de fontes diversas.
Analisamos que o recorte de realidade pode ser eleito por duas vias. A primeira, quando o professor, ao trabalhar a Metodologia da Problematização com seus alunos, escolhe uma unidade de ensino ou define a temática de pesquisa. Neste caso os participantes recebem o recorte de realidade definido. A segunda, quando o professor estimula os alunos a escolherem a temática, seja um aspecto da realidade ou um foco de pesquisa pelo qual o aluno se interesse. 
Assim, quando o aluno fizer um segundo recorte dentro do conteúdo da disciplina, ele recupera um saber curricular. Por exemplo, tomemos o tema avaliação, que faz parte do conteúdo da disciplina Didática. Os participantes, ao procederem ao segundo recorte, que envolve modalidades de avaliação, critérios, instrumentos, entre outros, irão fazê-lo pelos seus interesses advindos da sua experiência anterior (seja como aluno, professor, ou outra experiência). Então, neste caso, mesmo feito um segundo recorte, os saberes poderão estar associados a saberes disciplinares, curriculares ou experienciais.

Ainda podemos exemplificar de outra forma. Se o participante é professor, a escolha, o recorte do tema, pode vir de seu saber docente, advindo do seu trabalho em sala de aula ou até mesmo pedagógico, quando ele parte da necessidade de maior esclarecimento a respeito do tema.

Em síntese, esta ação inclui um misto de saberes, não se podendo afirmar abstratamente (generalizar) qual seja, pois depende de cada pessoa (das experiências que teve, se foram positivas, negativas etc.), ou seja, esses saberes não se resumem a um só domínio de conhecimento, porque envolvem a identidade do profissional, dependem da ação e da reflexão sobre o que faz, e também a maneira de pensar e de agir na realidade social na qual está inserido. Além disso, conta também com os saberes experienciais, que em geral são marcados por processos de ordem religiosa, pedagógica, familiar, social, entre outras, que podem ser acionados, entre outros que poderão ser aprendidos no próprio ato de eleger o recorte de realidade a ser observado.

Uma outra ação selecionada para análise foi prepara o necessário para a observação (do recorte eleito), que pode se realizar de diferentes modos. Os participantes podem aproximar-se do seu recorte por diferentes ângulos e usando diferentes procedimentos. Por exemplo, pode ocorrer uma observação direta de fatos na realidade social, sendo necessário para isso elaborar um instrumento de observação. Pode ocorrer a consulta a pessoas que se relacionam de alguma forma à temática, e, para isso, utilizam-se de instrumentos como: entrevistas, questionários, depoimentos escritos, uma única questão, entre outros. Pode ainda ser consultada a legislação a respeito do tema e para isso se utilizar a análise de conteúdo da legislação, entre outras possibilidades, como análise de filmes, fotografias, histórias, sem contar a necessária consulta à literatura.

Percebemos que saberes técnicos (disciplinares, no caso de se contar com uma disciplina de metodologia científica) e saberes pedagógicos iniciais estão aí envolvidos, para fundamentar tal preparação. E, ao tomar os cuidados necessários para os procedimentos e elaborar os instrumentos de observação, o participante tem a possibilidade de adquirir novos dessa natureza e fortalecer esses saberes. Ou seja, novamente é uma ação que mobiliza diferentes tipos de saberes, o que Tardif (2002) trata de amálgama de saberes.

Outra ação selecionada é analisa o registrado, em seu conteúdo, problematizando-o. Nessa ação, ao analisar o registrado, o participante o faz a partir de seus conhecimentos e experiências anteriores, mas também a partir de seus valores, suas crenças, seus sentimentos e necessidades. Por exemplo, ele pode realizar indagações relacionadas ao todo observado, buscando identificar o que deixou a desejar, o que pode ser considerado injusto, impróprio, insuficiente etc. É com valores e crenças que ele qualifica a situação e a julga adequada ou inadequada. Notamos que essa ação mobiliza saberes pedagógicos que envolvem o conhecimento cientifico e os saberes experienciais (valores, sentimentos).

Vejamos agora os saberes que associamos à segunda etapa. 


\begin{tabular}{|c|c|}
\hline $\begin{array}{c}\text { Ações relativas à } 2^{\mathrm{a}} \text { etapa da M. P. com o } \\
\text { Arco de Maguerez }\end{array}$ & Saberes associados às ações \\
\hline *Reflete a respeito do problema & \\
\hline $\begin{array}{l}\text { - Identifica possíveis fatores associados ao } \\
\text { problema }\end{array}$ & * experienciais; pedagógicos \\
\hline $\begin{array}{l}\text { - Identifica possíveis determinantes maiores do } \\
\text { problema }\end{array}$ & * temporais; experiências; \\
\hline $\begin{array}{l}\text { - Redige toda essa reflexão, extraindo o seu sentido } \\
\text { para o estudo, pelas possíveis explicações da } \\
\text { existência do problema }\end{array}$ & * curriculares \\
\hline $\begin{array}{l}\text { - Analisa a reflexão, captando os vários aspectos } \\
\text { envolvidos no problema }\end{array}$ & * experienciais; pedagógicos; profissionais \\
\hline $\begin{array}{l}\text { * Elege, com critérios, aqueles aspectos que serão } \\
\text { estudados na etapa seguinte } \\
\text { * Redige os pontos-chave (síntese clara) }\end{array}$ & $\begin{array}{l}\text { * experienciais; pedagógicos; profissionais } \\
\text { *curriculares }\end{array}$ \\
\hline
\end{tabular}

Quadro 7. Saberes associados às ações da etapa dos Pontos-chave

Selecionamos, nessa etapa, duas ações, sendo a primeira: identifica possiveis fatores associados ao problema. Notamos que a identificação desses possíveis fatores, advindos de situações diversas, ao se pensar o que estaria influindo para a existência do problema eleito, mobiliza tanto saberes experienciais quanto saberes pedagógicos (científicos).

Em outras palavras, o participante busca saber por que o problema está se apresentando. Recorre para isso às suas experiências passadas, tanto ao que já leu, ouviu, pensa, acredita ou valoriza em relação ao foco do problema e levanta hipóteses explicativas iniciais para que o mesmo esteja ocorrendo. Além disso, pode recorrer aos saberes obtidos por meio da literatura específica da temática envolvida, o que ultrapassa o senso comum. Por isso, afirmamos que estariam aí presente os saberes pedagógicos.

A segunda ação selecionada para ser explicada foi: identifica possiveis determinantes maiores do problema. Para realizar essa ação, o participante se pergunta a respeito de que aspectos políticos, econômicos e sociais etc. podem estar influindo para a existência do problema e dos próprios fatores já elencados. Para isso, realiza uma reflexão mais profunda, de aspectos nem sempre diretamente observados, mas que podem ser associados a situações vividas no seu cotidiano e que guardam relações com o contexto maior da sociedade, além de mobilizar valores e crenças que o participante possui para realizar tais associações.

Notamos, portanto, que essa ação envolve saberes temporais - advindos da vida em sociedade -, experienciais, assim como relacionados à ética (da observação do cumprimento ou não das leis produzidas pelos próprios homens).

Como na segunda etapa da M.P., os participantes lidam basicamente com seus conhecimentos prévios. Em geral, o que são solicitados a realizar é principalmente recorrer a eles e a tratá-los de modo coerente com o propósito da etapa. Além dos saberes que são acionados, ligados a conhecimentos, os participantes são levados a manifestar (se já 
aprenderam antes) ou a desenvolver, habilidades de lidar com eles, como é o caso da análise e da síntese, sempre solicitadas e nem sempre disponíveis, dado o tipo de escolarização ainda predominante em nosso meio.

Passamos a apresentar os saberes que estão associados à terceira etapa da M.P.

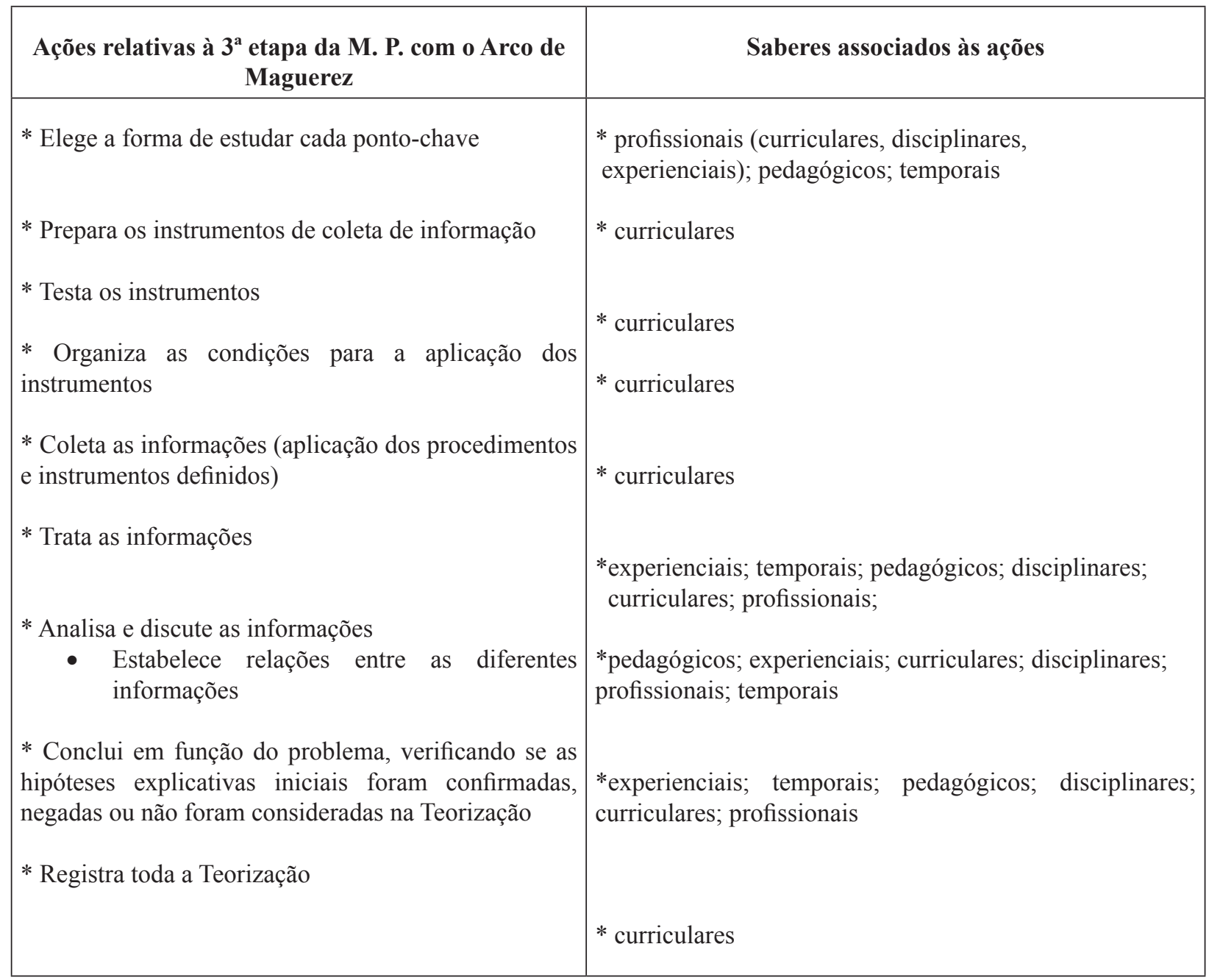

Quadro 8. Saberes associados às ações da etapa da Teorização

Da etapa da Teorização, selecionamos duas ações. A primeira: elege a forma de estudar cada ponto-chave. O participante, ao se preparar para o estudo dos pontos-chave, deverá decidir qual a forma mais adequada de investigá-los, ou seja, de esclarecer cada um dos Pontos-chave que, pela sua natureza, vai demandar um tipo de fonte ou de instrumento específico para sua investigação.
Assim, o participante decide pela literatura científica (teorias - saberes pedagógicos), por informações de especialistas (que possuem saberes profissionais), ou por outras formas de colher informações, como por exemplo, entrevistas junto às pessoas (adquirindo ou reforçando saberes profissionais, experenciais, temporais), análise de documentos, utilização de questionários, etc., 
associando formas que permitam relacionar teoria e prática, sempre com vistas à compreensão e solução do problema.

Ainda se pode esclarecer que se o ponto-chave for relativo à teoria (saberes pedagógicos), vai eleger a busca na biblioteca, na internet, em artigos, por meio de informações de especialistas, pesquisas de caráter histórico, técnico e científico, entre outros, que permitam construir respostas sobre os diferentes ângulos do problema.

A segunda ação selecionada foi: Analisa $e$ discute as informações. Coletadas as informações (em livros, artigos, entrevistas, legislação etc.), inicia-se, primeiramente, a análise das mesmas, que será feita em cada grupo de informações e também no conjunto das mesmas. O participante deverá verificar o que as informações têm em comum, o que elas têm de diferente, de contrastante, se existe uma tendência de pensamento permeando-as, entre outros aspectos, que podem ser considerados critérios de análise.

Para isso, são mobilizados e requeridos saberes pedagógicos (quando se apóia na teoria para perceber o sentido das manifestações), os saberes profissionais (quando contrasta as informações, envolvendo o que já conhecia sobre o assunto e o que passa a conhecer), além dos saberes disciplinares e experienciais (que foram adquiridos nos cursos de formação em diferentes sentidos, inclusive no desenvolvimento de habilidades de pensamento, como a de análise).

A discussão vem a seguir ou no próprio movimento de análise, quando o participante procura relacionar/confrontar os diferentes grupos de informações entre si. Por exemplo, as informações obtidas por meio de entrevistas ou questionários serão comparadas com informações da literatura, verificando a convergência ou não das idéias. O participante busca, pela análise e discussão, os elementos conclusivos da investigação, mobilizando os mesmos saberes. Ocorrem possibilidades de reforçar posições existentes anteriormente ou de reformular as posições iniciais (saberes temporais), o que provoca uma nova compreensão a respeito do problema.

Desse modo, esse processo de reflexão possibilita uma aquisição de novos saberes acerca do objeto de estudo (disciplinares, curriculares, experienciais), mobilizando o potencial reflexivo dos participantes (curriculares, pedagógicos e experienciais), preparando-os para a etapa seguinte, quando pensarão em possíveis caminhos para a superação do problema.

A seguir, apresentamos as ações da quarta etapa e seus saberes associados. 


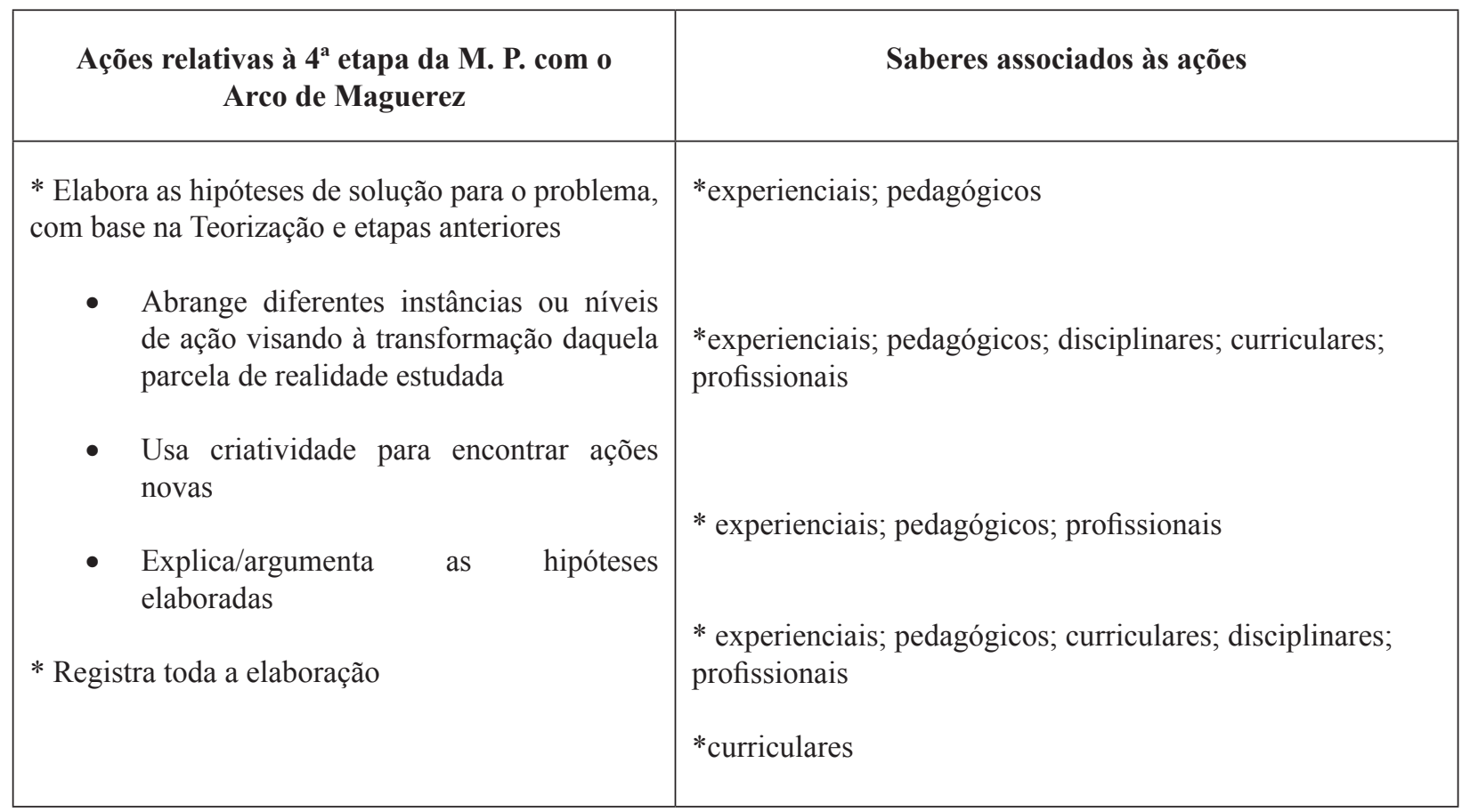

Quadro 9. Saberes associados às ações da etapa Hipóteses de Solução

Selecionamos para análise a ação: elabora as hipóteses de solução para o problema, com base na Teorização e etapas anteriores. Nesta ação, todas as possibilidades de solução ou encaminhamento de solução para o problema são pensadas, registradas e ainda analisadas, visando uma total coerência com o problema, o que envolve tanto os saberes pedagógicos e disciplinares (quando associa com a teoria considerada no estudo), quanto os curriculares (no momento de eleger novos caminhos), experienciais (quando busca superar as experiências anteriores), e profissionais (quando considera os encaminhamentos mais adequados para a possível superação do problema educacional). Tais hipóteses poderão abranger diferentes instâncias às quais são atribuídas ações de transformação daquela parcela de realidade estudada, envolvendo saberes pedagógicos e disciplinares (associados às teorias), curriculares e temporais (visando a ações de transformação voltadas para o futuro próximo), relacionadas a questões éticas, político-pedagógicas e sociais.
Essa ação, portanto, de modo criativo, e utilizando os conhecimentos anteriores e os adquiridos pelo estudo, leva o participante a encontrar ações novas em busca da solução do problema e provoca o seu desenvolvimento crítico e reflexivo para a atuação na realidade estudada, antecedendo a prática (tanto social, quanto política) que corresponde à última etapa.

Tais hipóteses devem ser explicadas/ argumentadas, demonstrando o sentido das mesmas em relação ao problema. Nesse momento, o participante se utiliza de um misto de saberes (experienciais, pedagógicos, curriculares, disciplinares e profissionais), buscando mostrar como as novas ações sugeridas por ele poderão contribuir para a superação do problema.

Por fim, apresentamos a associação das ações e saberes na quinta etapa. 


\begin{tabular}{|l|l|}
\hline \multicolumn{1}{|c|}{$\begin{array}{c}\text { Ações relativas à 5 } \mathbf{5}^{\text {a }} \text { etapa da M. P. com o } \\
\text { Arco de Maguerez }\end{array}$} & \multicolumn{1}{c|}{ Saberes associados às ações } \\
\hline *Analisa a aplicabilidade das hipóteses & *experienciais; pedagógicos; profissionais \\
$\begin{array}{l}\text { *Elege, com critérios (exeqüibilidade, urgência, prioridade } \\
\text { etc.) as que julga poder colocar em prática }\end{array}$ & *experienciais; curriculares; \\
* Planeja a execução das ações pelas quais se compromete & $*$ experienciais; curriculares \\
*Executa as ações planejadas & $*$ profissionais; experienciais; temporais \\
*Registra todo o processo, analisando os resultados & $*$ experenciais; curriculares \\
\hline
\end{tabular}

Quadro 10. Saberes associados às ações da etapa Aplicação à Realidade.

Para exemplificar a razão da associação de saberes às ações da etapa Aplicação, selecionamos duas ações. A primeira: analisa a aplicabilidade das hipóteses. Neste momento, o participante tem a possibilidade de, por meio dessa ação, analisar de forma reflexiva as condições objetivas de aplicabilidade das hipóteses elaboradas na parcela de realidade estudada. Por exemplo, se a ação relativa a uma das hipóteses foi atribuída a algum setor um pouco distante do participante, como providências pelo Colegiado de um curso de uma IES, por um professor de uma disciplina, famílias etc., o participante pode pensar em como encaminhar sugestões e ou reivindicações, ou ainda marcar uma entrevista para conversar sobre a necessidade da ação. Em outras situações, mais próximas do participante, ele pode analisar a possibilidade de assumir a sua execução.

Enfim, analisa uma a uma as hipóteses elaboradas na etapa anterior, para eleger as que poderão ser colocadas em prática nesta etapa. Essa ação envolve saberes experienciais, quando o participante faz relação com a prática educacional que conhece; saberes pedagógicos, quando lança mão de aspectos teóricos para analisar a pertinência das hipóteses com as situações da realidade para decidir a sua aplicação e a atribuição da mesma à instância sugerida, quanto da viabilidade de encaminhamento das providências por si mesmo; saberes profissionais quando reúne todas as informações necessárias para imaginar a possível aplicação das hipóteses.

Isso significa que, além de mobilizar informações que ultrapassam a simples memorização, essa ação permite a mobilização de habilidades de pensamento de nível superior para vislumbrar a relação teoriaprática das diferentes hipóteses elaboradas, preparando-se para eleger as que vai executar, o que envolve diferentes tipos de saberes adquiridos ao longo da vida quanto na formação profissional e no próprio estudo do problema, desde o início da sua observação.

A segunda ação selecionada: executa as ações planejadas, permite um conjunto de ações concretas pelo participante. É chegado o momento da prática transformadora, em algum grau, aquele possível, no contexto a partir do qual o problema foi identificado. É o momento da utilização de saberes profissionais de várias ordens, tais como de habilidades de comunicação, manifestação de conteúdos, de estratégias de ação, de cuidados éticos, com a intencionalidade de intervir positivamente naquela parcela de realidade para contribuir para a superação do problema.

Desse modo, os saberes experienciais e temporais também contribuem para sinalizar a coerência e adequação de tais aplicações. Nesse momento, quando o participante executa seus compromissos 
de ação transformadora, prepara-se para atuações profissionais, sociais e políticas futuras, de modo mais consciente, informada, crítica, criativa e intencionalmente transformadora, (re) construindo para si mesmo e para interagir com outros de seu meio, novos conhecimentos, exercitando sua cidadania.

Pensamos que, por meio da associação entre as ações das etapas da M.P. e os saberes de professores e dos exemplos selecionados e exemplificados acima, tenhamos atingido o objetivo a que nos propusemos, disponibilizando essa elaboração para a continuidade de reflexões e aplicações da Metodologia da Problematização pelos seus interessados.

\section{Conclusão}

Ao analisarmos a temática saberes de professores, definida como um dos focos da pesquisa, foi possível entender que esses saberes não se limitam aos conhecimentos disciplinares, pois há que considerar os conhecimentos advindos da identidade do profissional, que depende de alguns fatores, como a formação, a ação e reflexão sobre o que faz e a relação que estabelece com a realidade social na qual está inserido, entre outros.

Para isso, a formação profissional exige um aprofundamento de saberes técnicos e científicos, incluindo a sua dimensão ética, a partir dos quais os conhecimentos de ordem religiosa, pedagógica, familiar, pessoal, social, entre outros, são acionados, confrontados, reforçados ou revistos, no sentido de constituir um tipo de formação profissional.

Desse modo, o trabalho dos professores, bem como seus saberes, devem ser considerados num espaço prático e específico de produção, de transformação e de mobilização de outro saberes. Ou seja, o exercício da docência exige um conjunto de saberes que são essenciais para o seu desenvolvimento e podem ser adquiridos em várias instâncias educacionais e sociais (formais e não formais).
Tivemos, como objetivo geral desta investigação, "Analisar o potencial da Metodologia da Problematização com o Arco de Maguerez para o desenvolvimento de saberes inerentes à formação e atuação do professor, ou de participantes de outras áreas". Para atingir esse objetivo, descrevemos as etapas e características da Metodologia da Problematização com o arco de Maguerez, a partir de referenciais que tratam da mesma, no primeiro item. Na seqüência, identificamos e caracterizamos um conjunto de saberes próprios da profissão do professor, a partir de autores que tratam dessa temática, o que apresentamos no segundo item. No terceiro item, sintetizamos as ações contidas nas cinco etapas da Metodologia da Problematização, com o Arco de Maguerez e, no quarto item, demonstramos a relação que conseguimos perceber entre as contribuições a respeito dos saberes de professores e as características da Metodologia da Problematização, buscando identificar o potencial dessa metodologia sob esse ponto de vista. Desse modo, podemos afirmar que alcançamos as expectativas definidas como objetivos para a investigação.

Pudemos perceber e retratar também a importância da Metodologia da Problematização e seu efetivo potencial pedagógico, ao ser realizada por meio das cinco etapas do Arco de Maguerez. Por todo o estudo realizado, pela análise das etapas da Metodologia, foi possível extrair confirmações de que existem vários saberes envolvidos nesse processo e que dão suporte aos professores e participantes que dela se utilizam.

Assim, respondendo ao problema: "Quais são os saberes que podem ser mobilizados/estimulados, por meio da Metodologia da Problematização com o Arco de Maguerez, em seus participantes", identificamos e demonstramos, no item três, que os saberes docentes, profissionais, pedagógicos, disciplinares, curriculares, experienciais, e, como ressalta Tardif (2002), os saberes temporais, estão diretamente associados a diferentes momentos do processo de aplicação da M.P.. 
Verificamos, pelo estudo, que as ações dos professores não podem ser vistas como meras tarefas de um técnico ou de um executor, pois os professores são sujeitos que possuem, utilizam e produzem saberes específicos ao seu trabalho. Assim, a Pedagogia não pode ser outra coisa senão a prática de um profissional. Tanto em suas bases teóricas quanto em suas conseqüências práticas, os saberes profissionais são evolutivos e progressivos e necessitam, portanto, de uma formação contínua e de um reciclar-se pelo professor através de diferentes meios. Acreditamos que há a necessidade de uma tomada de consciência dos diferentes saberes que fundamentam a profissão docente, levando também o professor à construção de sua identidade profissional na prática educativa.

Neste caso, a Metodologia da Problematização com o Arco de Maguerez se faz de extrema relevância nesse processo, quando os professores que a utilizam em estudos de seu interesse ou no ensino/ pesquisa para a formação de novos professores, são estimulados a ampliar seus saberes, transformandose e buscando transformar a realidade, nos aspectos que se fazem necessários.

Concluímos que as ações da Metodologia da Problematização, relacionadas a diferentes saberes, proporcionam aos participantes ultrapassarem a simples retenção de informações na memória, desenvolvendo habilidades reflexivas e criativas, que permitem mobilizar os saberes que já possuem e adquirir outros em diferentes dimensões, como a técnica, a científica, a política e a social, construindo e reconstruindo a sua prática pedagógica.

Com esta investigação, portanto, acreditamos ter construído alguns passos a mais como uma contribuição a ser acrescentada aos conhecimentos já existentes a respeito da Metodologia da Problematização com o Arco de Maguerez.

\section{Referências}

BERBEL, N. A. N. Metodologia da problematização: experiências com questões de ensino superior. Londrina: EDUEL, 1998a.
BERBEL, N. A. N. Metodologia da problematização: experiências com questões de ensino superior, ensino médio e clínica. Londrina: EDUEL, 1998b.

. Metodologia da problematização: uma alternativa metodológica apropriada para o ensino superior. Semina: Ciências Humanas e Sociais, Londrina, v. 16, n. 2, p. 9-19, out. 1995.

(Org.). Metodologia da Problematização no Ensino Superior e o exercício da práxis. Semina: Ciências Humanas e Sociais, Londrina, v.17, Ed. Especial, nov./1996.

. Metodologia da problematização: fundamentos e aplicações. Londrina: EDUEL, 1999.

- (Org.). Conhecer e intervir: o desafio da metodologia da problematização. Londrina: EDUEL, 2001.

O exercício da práxis por meio da metodologia da problematização: uma contribuição para a formação de profissionais da educação, 2007. In: BEHRENS, M. A.; ENS, R. T.; VOSGERAU, D. S. R. (Org.). Discutindo a educação na dimensão da práxis. Curitiba: Champagnat, 2007. v. 1, p. 149-164.

BORDENAVE, J. D.; PEREIRA, A. M. Estratégias de ensino aprendizagem. 4. ed. Petrópolis: Vozes, 1989.

LUDKE, M.; ANDRÉ, M. E. D. A. A pesquisa em educação: abordagens qualitativas. São Paulo: EPU, 1986.

NUNES, C. M. F. Saberes docentes e formação de professores: um breve panorama da pesquisa brasileira. 2001. Disponível em: <http://www.scielo.br/pdf/es/ v22n74/a03v2274.pdf>. Acesso em: 20 out. 2006.

PIMENTA, S. G. Formação de professores: identidade e saberes da docência. In: _ (Org.). Saberes pedagógicos e atividade docente. São Paulo: Cortez, 1999.

PINTO, Maria das Graças C. da S. M. Gonçalves. A docência na educação superior: saberes e identidades. 2003. Disponível em: http://www.anped.org.br/ reunioes/28/textos/gt04/GT04-1245--Int.rtf. Acesso em: 15 out. 2006.

RICHARDSON, R. J.; PERES, J. A.; WANDERLEY, J. C. V.; CORREIA, L. M.; PERES, M. H. Pesquisa social: métodos e técnicas. 3. ed. São Paulo: Atlas, 1999.

TARDIF, M. Saberes docentes e formação profissional. Petrópolis: Vozes, 2002.

VASCONCELLOS, M. M. M. Aspectos pedagógicos e filosóficos da metodologia da problematização. In: BERBEL, N. A. N. Metodologia da problematização: fundamentos e aplicações. Londrina: EDUEL, 1999. p. 29-59. 